\title{
Ek sal Coetzee net wil observeer om hom (dalk) beter te begryp
}

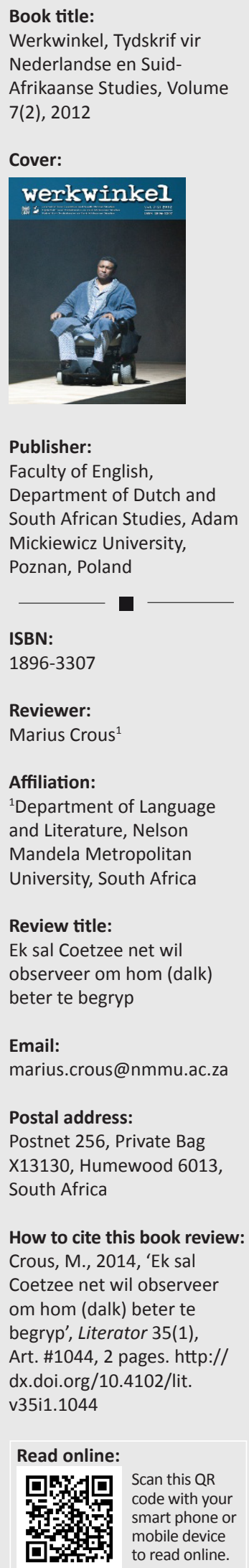

Dié uitgawe van die drietalige tydskrif wat deur die Universiteit van Poznan in Pole gepubliseer word, word spesifiek gewy aan die lewe en werk van J.M. Coetzee.

Op 09 Julie 2012 het die Adam Mickiewicz Universiteit (AMU) in Poznan 'n eredoktorsgraad aan dié beroemde skrywer toegeken en gevolglik is besluit om 'n hele uitgawe van die tydskrif aan hom te wy.

Naas Coetzee se lectio, bevat dié tydskrif ook onderhoude, foto's, akademiese artikels, resensies en 'n huldigingswoord vir J.C. Kannemeyer, die biograaf van J.M. Coetzee. Op 05 Julie 2012 het die wêreldpremiere van die opera Slow man in Poznan plaasgevind en 'n onderhoud met Maja Kleczewska wat die regisseur was, word ook in Werkwinkel opgeneem. Interessant is die feit dat Coetzee self die libretto geskryf het. Onderhoude met Nicholas Lens, die komponis en Krzysztof Warlikowski, 'n ander Poolse regisseur, word ook in die tydskrif ingesluit.

In sy lectio posisioneer Coetzee homself as skrywer en fokus hy onder meer op kwessies soos identiteit, taal en sy besluit om te begin skryf. Wat sy identiteit betref, vra hy die vraag: 'How was it, that I, who had not a drop of English blood in my veins, had grown up speaking and eventually writing in a foreign language, English?' Wat die besluit om skrywer te word betref, verwys Coetzee na 'n voorsaat van hom wat ook geskryf het en wat hom tot die besef laat kom het dat as grootoom Albert dit kon doen, kon hy ook. Kenmerkend relativerend, beskou Coetzee die drang om te skryf soos volg:

One writes because one is good at writing. One writes because one feels called to spread one's individual word. One writes because what one wants to give voice to happens to be what the world wants to hear at that moment in time; or vice versa.

Dié skrywende oom van Coetzee was toevallig 'n Poolse boorling en Coetzee vind dit dus gepas om by dié geleentheid hierop te fokus. Die toespraak van Coetzee is 'n kort, maar kragtige boodskap oor globalisering, oor etniese verwarring en oor die daad van skryf.

Die onderhoud met die Coetzee-kenner, Derek Attridge, sluit hierby aan en fokus onder meer op die politieke rol van die kunste, asook daardie brandende kwessie waaroor skrywers moet besin. Op grond van uitsprake deur Coetzee (1997) in Giving offense, kom Attridge tot dié slotsom:

Coetzee offers a clear account of the role of the writer as deriving his or her power, such as it is, from not espousing a fixed position, and Coetzee has tried to produce a kind of art that embodies this ironic commitment-without-finality.

Wat die akademiese artikels betref, ondersoek Pauline Grzeda Coetzee se bydrae tot die outobiografie, maar veral sy eties - politiese standpuntinname in sy persoonlike skryfwerk. Eerder as om voor te gee om 'n betrokke skrywer te wees en sy diskursiewe posisie luidkeels te verkondig, verkies hy om in sy romans belangrike standpunte in te neem teenoor onderdrukking en veral geestelik intellektuele inperkinge wat op die individu afgedwing word.

Sedert die dae van sy doktorale proefskrif oor Beckett was daar nog altyd sprake van 'n Beckettiaanse inslag in Coetzee se werk en dit is ook die onderwerp van Tomasz Wisniewski se artikel. Hy betrek veral kritiese werk wat Coetzee oor Beckett self geskryf het en spesifiek sy Eight ways of looking at Samuel Beckett, waarin hy onder meer akademiese skryfwerk parodieer, besin oor die lot van laboratoriumdiere en kommentaar lewer op eksistensiële ontheemdheid. Lesers van Coetzee se werk sal al drie hierdie aspekte in sy eie werk herken.

Katarzyna Karwowska ondersoek die uitbeelding van ruimtes en plekke in Coetzee se werk en poog om die leemtes in bestaande kritiek oor die skep van literêre plekke met betrekking tot postmoderne teoretisering oor ruimte te ondervang. Aan die hand van Deleuze en Guattari

Copyright: @ 2014. The Authors. Licensee: AOSIS OpenJournals. This work is licensed under the Creative Commons Attribution License. 
ondersoek sy die nomadiese Michael K se swerftog vanuit die gefiksionaliseerde Kaapstad na die Karoo.

'n Besondere bydrae in die tydskrif is Jerzy Koch se palimpses, waarin hy probeer om soos in Slow man verskeie tekslae te inkorporeer.

Hierdie uitgawe van Werkwinkel is betekenisvol, want dit bied aan die Suid-Afrikaanse leser 'n ander blik op Coetzee en Coetzee se skryfwerk. Om vanuit 'n eertydse kommunistiese land na Coetzee se werk oor die verlooptes, die ontheemdes en die swerwendes te kyk, lei noodwendig tot nuwe perspektiewe. Warlikowski meen trouens in sy onderhoud dat Coetzee oor die val van die mensdom besin.
Skerpsinnig beveel hy aan dat Coetzee nie toneelstukke moet begin skryf nie en dat hy nie juis vrae aan Coetzee wil stel nie: 'I would like to observe him for a while. I would like to sit down, look, and try to understand'.

Want selfs ná hierdie uitgawe met sy foto's van Coetzee in akademiese drag, as toehoorder tussen 'n groep jong studente, asook die aangrypende foto's wat geneem is tydens die opvoerings oor en van sy werk, bly Coetzee steeds 'n enigma.

\section{Literatuurverwysings}

Coetzee, J.M., 1997, Giving offense: Essays on censorship, University of Chicago Press, Chicago. 